\title{
BIODIVERSITY AND LENGTH FREQUENCIES OF SHARKS CAUGHT IN THE INDIAN OCEAN
}

\author{
Dharmadi $^{1}$, K. Sumadhiharga ${ }^{2^{\star}}$ and Fahmi $^{2}$ \\ Research Centre for Captured Fisheries, Department of Marine Affairs and Fisheries \\ Jl. Pasir Putih I, Ancol Timur, Jakarta Utara, Indonesia \\ ${ }^{2}$ Research Centre for Oceanography, Indonesia Institute of Sciences \\ J1. Pasir Putih I, Ancol Timur, Jakarta Utara, Indonesia, \\ •e-mail: ono_ks@indo.net.id
}

\begin{abstract}
Study on biodiversity and size structure of sharks in the Indian Ocean was conducted at several landing sites and fish markets, i.e. Pelabuhanratu (West Java), Cilacap (Central Java), Kedonganan (Bali) and Tanjung Luar (East Lombok ). Field observation was done from April 2001 to March 2006. The results showed that there were 86 species of sharks belonging to 16 families in the Indian Ocean. The sharks were dominated by family of Carcharhinidae and Squalidae with 24 and 23 species, respectively. A high diversity of sharks was found at Kedonganan-Bali (49 species), at Tanjung Luar (47 species), at Cilacap (32 species) and at Pelabuhanratu (27 species). Size of sharks landed at those landing sites varied in length, the length of Carcharhinus amblyrhynchos was between $90 \mathrm{~cm}$ and $170 \mathrm{~cm} \mathrm{TL}$, C. sorrah $(55-155 \mathrm{~cm})$, C. obscurus $(205-295 \mathrm{~cm})$ and $P$ glauca was caught at length between 205-300 $\mathrm{cm}$.
\end{abstract}

Keywords: Sharks, Biodiversity, Length frequencies, Indian Ocean

\section{INTRODUCTION}

Sharks are classified in the order of Selachii, which together with the skates and rays of the order of Batoidei make up the sub class Elasmobranchii, and sharks are dominant fishes among the cartilaginous fishes (Demski and Wourms, 1993). The diversity of the cartilaginous fishes was significantly high in Indonesian waters (Gloerfelt-Tarp and Kailola, 1984; Last and Stevens, 1994; Carpenter and Niem, 1998). According to Goerfelt-Tarp and Kailola (1984), sharks consisted of 84 species which were caught by trawls in the southern Indonesian waters and the north-west of Australia. Whiles the diversity of sharks was recorded of about 375 to 500 species in the world, which were dominated by order Carcharhiniformes (ground sharks; 56\%). Other major groups of Elasmobranchs are Squaliformes (dogfish sharks), Orectolobiformes (carpet sharks), and Lamniformes (mackerel sharks) that respectively comprise $23 \%, 8 \%$, and $4 \%$ of the living sharks (Demski and Wourms, 1993; FAO, 2000).

Indonesia is known as having the highest diversity of elasmobranches (sharks and rays) in the world (Blaber, 2006), with their fishery production reported as 87,138 tones in 1993 and 100,000 tones in 1996 (Monintja and Poernomo, 2000; Widodo, 2000). In 2004, sharks and rays were landed about 108,694 tones (Directorate General of Capture Fisheries, 2006), and approximately 60,000 tones of sharks, which was significantly decreasing (Blaber, 2006). Various parts of shark body could be utilized such as their meats and fins for foods, skins for leather industries, and liver oil and cartilages for medicines. The most valuable part of the shark body is its fins, and they are usually exported to Asian countries (Anonymous, 2003). Whiles the salted and dried shark meat are traded either locally or exported especially to Bangladesh and Srilangka (Pers. comm.). Trade statistics revealed that, during 2000 and 2001, Hongkong imported 1,400 tones of shark fins, (both 
with and without cartilages) from Indonesia (Anonymous, 2003). Squalene oil is commonly produced from the shark liver especially from the family Squalidae and it is exported to almost Asian countries (Blaber, 2006).

Sharks are usually caught locally as target fisheries and also as by catch. Target fisheries use a variety of fishing methods, such as gill and tangle nets, long lines and harpoons (Dharmadi and Fahmi, 2003). Although Indonesia has the largest shark fishery and is considered to have one of the richest sharks in the world, but there is almost no information on biological data or size compositions of species landed. In a region where shark populations are amongst the most heavily exploited, taxonomic knowledge of Indonesia's sharks needs improving to provide an adequate baseline for data acquisition and resource management.

The size of sharks from Indian Ocean varied in lengths which were depending on both species and their habitat. Their length frequencies could be use for either their growth or age estimation (Sparre and Venema, 1992). Despite of their abundance, elasmobranchs are particularly vulnerable to over fishing due to their biological characteristics. Sharks and rays are slow maturing and long lived, but do not have high levels of fecundity (Wourms and Leo, 1993). This paper presents information on shark diversity and size composition of some sharks species caught from the Indian Ocean.

\section{MATERIALS AND METHODS}

Study on elasmobranch species was conducted from April 2001 to March 2006 at several landing sites along the coast of Indian Ocean, particularly from Pelabuhanratu (West Java), Cilacap (Central Java), Kedonganan (Bali), and Tanjung Luar (East Lombok), Those sites were visited regularly during the study. Twenty one trips were done in Kedonganan and Tanjung Luar, and 15 trips were done in Cilacap and Pelabuhanratu (Fig. 1). Each trip was conducted within $2-7$ days.

Shark species was identified using descriptions in Compagno et al.(1984), Last and Stevens (1994), Compagno $(1998 ; 1999)$ and Gloerfelt-Tarp \& Kailola (1984). All measurements of sharks referred to their total length (TL), which was measured as a straight line from the tip of the snout to the tip of the extended upper caudal-fin lobe. Length frequency assessments were analyzed to only four carcharhinid species, which were Carcharhinus amblyrhynchos, C. sorrah, C. obscurus and Prionace glauca.

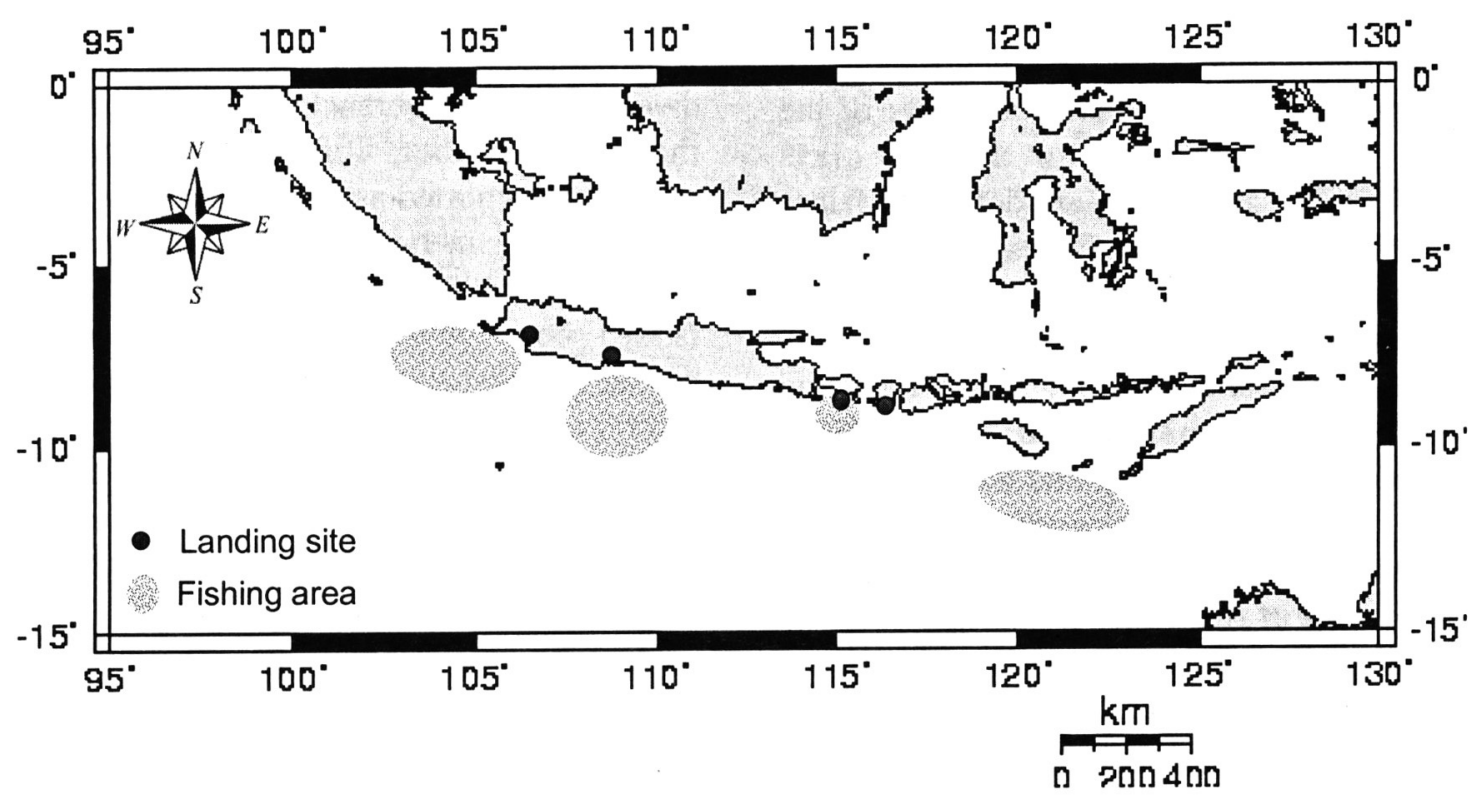

Figure 1. Map of the study area and observed landing sites Java, Bali and West Nusa Tenggara. 


\section{RESULTS}

\section{Biodiversity}

From four landings, we identified 86 species of sharks belonging to 16 families. The dominant families were the Carcharhinidae (27\%), and the Squalidae (26\%).The highest diversity of sharks was found in Kedonganan (44 species), while from Tanjung Luar was found 45 species, Cilacap was 31 species, and Palabuhanratu was 27 species. All species found are listed in Table 1. In general, the most common shark species found in Indian Ocean was Carcharhinus falciformis, and the dominant families were Carcharhinidae and Squalidae (Table 1; Fig. 2).

Table 1. Diversity of Sharks in Indian Ocean from Pelabuhanratu, Cilacap, Kedonganan and Tanjung Luar landing sites.

\begin{tabular}{|c|c|c|c|c|c|}
\hline \multirow{2}{*}{ Family and Species } & \multirow{2}{*}{ Common Names } & Palabuhanratu & Cilacap & Kedonganan & Tj. Luar \\
\hline & & (West Java) & (Central Java) & (Bali) & (East Lombok) \\
\hline \multicolumn{6}{|l|}{ Hexanchidae } \\
\hline Heptranchias perlo & Sharpnose Sevengill Shark & + & + & + & \\
\hline Hexanchus griseus & Bluntnose Sixgill Shark & & & + & + \\
\hline \multicolumn{6}{|l|}{ Squalidae } \\
\hline Centrophorus cf. isodon & Blackfin Gulper Shark & & & + & + \\
\hline Centrophorus sp. 1 & Gulper Shark & & & + & \\
\hline Centrophorus cf granulosa & Gulper Shark & & & + & + \\
\hline Centrophorus lusitanicus & Largefin Gulper Shark & & & & + \\
\hline Centrophorus cf moluccensis & Smallfin Gulper Shark & & & + & \\
\hline Centrophorus cf niakung & Taiwan Gulper Shark & + & + & + & \\
\hline Centrophorus cf squamosus & Leafscale Gulper Shark & + & + & + & \\
\hline Centrophorus cf uyato & - & & & + & + \\
\hline Cirrhigaleus cf barbifer & Mandarin Dogfish & & & + & + \\
\hline Isistius brasiliensis & Cookiecutter Shark & + & + & + & + \\
\hline Squalus of japonicus & Japanese Spurdog & & + & + & \\
\hline Squalus sp. 1 & $\begin{array}{l}\text { Indonesian Greeneye } \\
\text { Spurdog }\end{array}$ & + & + & + & + \\
\hline Squalus sp. 2 & $\begin{array}{l}\text { Indonesian Greeneye } \\
\text { Spurdog }\end{array}$ & + & & + & + \\
\hline Squalus sp. 3 & Indonesian Shortnose Spurdog & & + & + & \\
\hline Squalus sp. C & Indonesian Highfin Spurdog & & + & + & + \\
\hline Centrophorus cf atromarginatus & Dwarf gulper shark & + & & & \\
\hline \multicolumn{6}{|l|}{ Orectolobidae } \\
\hline Orectolobus sp. 1 & Spotted wobbegong & & & + & + \\
\hline Orectolobus cf. japonicus & Japanese wobbegong & + & & & \\
\hline Orectolobus cf. ornatus & Indo wobbegong & + & & & \\
\hline \multicolumn{6}{|l|}{ Hemiscyllidae } \\
\hline Chiloscyllium punctatum & Brownbanded Bambooshark & & & + & + \\
\hline Chiloscyllium sp. cf. punctatum & Brownbanded Bambooshark & & & & + \\
\hline \multicolumn{6}{|l|}{ Stegostomatidae } \\
\hline Stegostoma fasciatum & Zebra shark & & & & + \\
\hline \multicolumn{6}{|l|}{ Ginglymostomatidae } \\
\hline Nebrius ferrugineus & Tawny nurse shark & & & + & + \\
\hline \multicolumn{6}{|l|}{ Odontaspididae } \\
\hline Carcharias taurus & Sand tiger shark & & & + & \\
\hline \multicolumn{6}{|l|}{ Pseudocarchariidae } \\
\hline Pseudocarcharias kamoharai & Crocodile Shark & + & + & + & + \\
\hline \multicolumn{6}{|l|}{ Alopiidae } \\
\hline Alopias pelagicus & Pelagic Thresher & & + & + & + \\
\hline Alopias superciliosus & Bigeye Thresher & + & + & & \\
\hline
\end{tabular}




\begin{tabular}{|c|c|c|c|c|c|}
\hline \multirow{2}{*}{ Family and Species } & \multirow{2}{*}{ Common Names } & Palabuhanratu & Cilacap & Kedonganan & Tj. Luar \\
\hline & & (West Java) & (Central Java) & (Bali) & (East Lombok) \\
\hline \multicolumn{6}{|l|}{ Lamnidae } \\
\hline Isurus oxyrinchus & Shorttin Mako & + & + & + & + \\
\hline Isurus paucus & Longfin Mako & & & 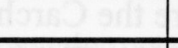 & + \\
\hline \multicolumn{6}{|l|}{ Scyliorhinidae } \\
\hline Atelomycterus marmoratus & Coral catsharks & & & + & + \\
\hline Atelomycterus sp. cf. marmoratus & Coral catsharks & & & + & 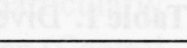 \\
\hline Cephaloscyllium sp. E & - & & & + & + \\
\hline Cephaloscyllium sp. & - & & + & & \\
\hline Haleolurus boesamani & Speckled catshark & & + & + & \\
\hline Parmaturus cf melanobranchius & & + & 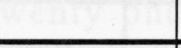 & $\underline{-}$ & \\
\hline \multicolumn{6}{|l|}{ Triakidae } \\
\hline Hemitriakis of leucoperiptera & & & 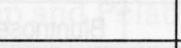 & + & + \\
\hline Hemitriakis sp. 1 & Indonesian houndshark & & & + & \\
\hline Mustelus cf griseus & Spotless smoothhound & + & + & + & + \\
\hline Mustelus sp. 1 & Whitefin smoothhound & & 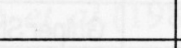 & + & \\
\hline Mustelus sp. 2 & Blackfin smoothhound & & 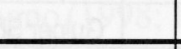 & + & + \\
\hline \multicolumn{6}{|l|}{ Hemigaleidae } \\
\hline Chaenogaleus macrostoma & Hooktooth shark & & + & 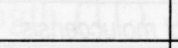 & \\
\hline Hemigaleus microstoma & Sicklefin weasel shark & 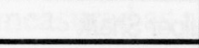 & - & + & + \\
\hline \multicolumn{6}{|l|}{ Carcharhinidae } \\
\hline Carcharhinus albimarginatus & Silvertip shark & + & & + & + \\
\hline Carcharhinus altimus & Bignose shark & & 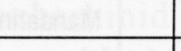 & 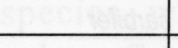 & + \\
\hline Carcharhinus amblyrhynchos & Grey reef shark & + & - & 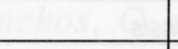 & + \\
\hline Carcharhinus amboinensis & Pigeye shark & 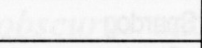 & 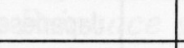 & + & + \\
\hline Carcharhinus brevipinna & Spinner shark & + & + & + & + \\
\hline Carcharhinus dussumieri & Whitecheeks shark & & 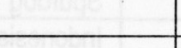 & & \\
\hline Carcharhinus falciformis & Silky shark & + & + & + & + \\
\hline Carcharhinus leucas & Bull shark & 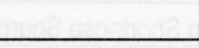 & + & & 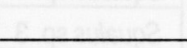 \\
\hline Carcharhinus limbatus & Common blacktip shark & 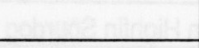 & + & + & + \\
\hline Carcharhinus longimanus & Oceanic whitetip shark & & + & & + \\
\hline Carcharhinus macloti & Hardnose shark & + & + & & 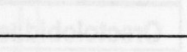 \\
\hline Carcharhinus melanopterus & Blacktip reefs shark & & 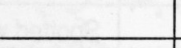 & + & + \\
\hline Carcharhinus plumbeus & Sandbar shark & & + & . & + \\
\hline Carcharhinus obscurus & Dusky whaler & & + & + & + \\
\hline Carcharhinus sorrah & Spot-tail shark & + & + & + & + \\
\hline Galeocerdo cuvier & Tiger shark & & + & 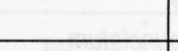 & + \\
\hline Loxodon macrorhinus & Sliteye shark & + & & & + \\
\hline Prionace glauca & Blue shark & & + & & + \\
\hline Rhizoprionodon acutus & Milk shark & + & + & + & + \\
\hline Rhizoprionodon oligolinx & Grey sharpnose shark & + & + & 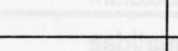 & + \\
\hline Triaenodon obesus & Whitetip reef shark & + & 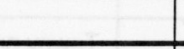 & + & + \\
\hline \multicolumn{6}{|l|}{ Sphyrnidae } \\
\hline Sphyrna lewini & Hammerhead shark & + & + & + & + \\
\hline Sphyrna mokarran & Hammerhead shark & & & & + \\
\hline Sphyrna zygaena & Hammerhead shark & + & + & & \\
\hline \multicolumn{6}{|l|}{ Squatinidae } \\
\hline Squatina sp & Angelshark & + & & & \\
\hline Total families & & 12 & 10 & 14 & 15 \\
\hline Total species & & 27 & 31 & 44 & 45 \\
\hline
\end{tabular}




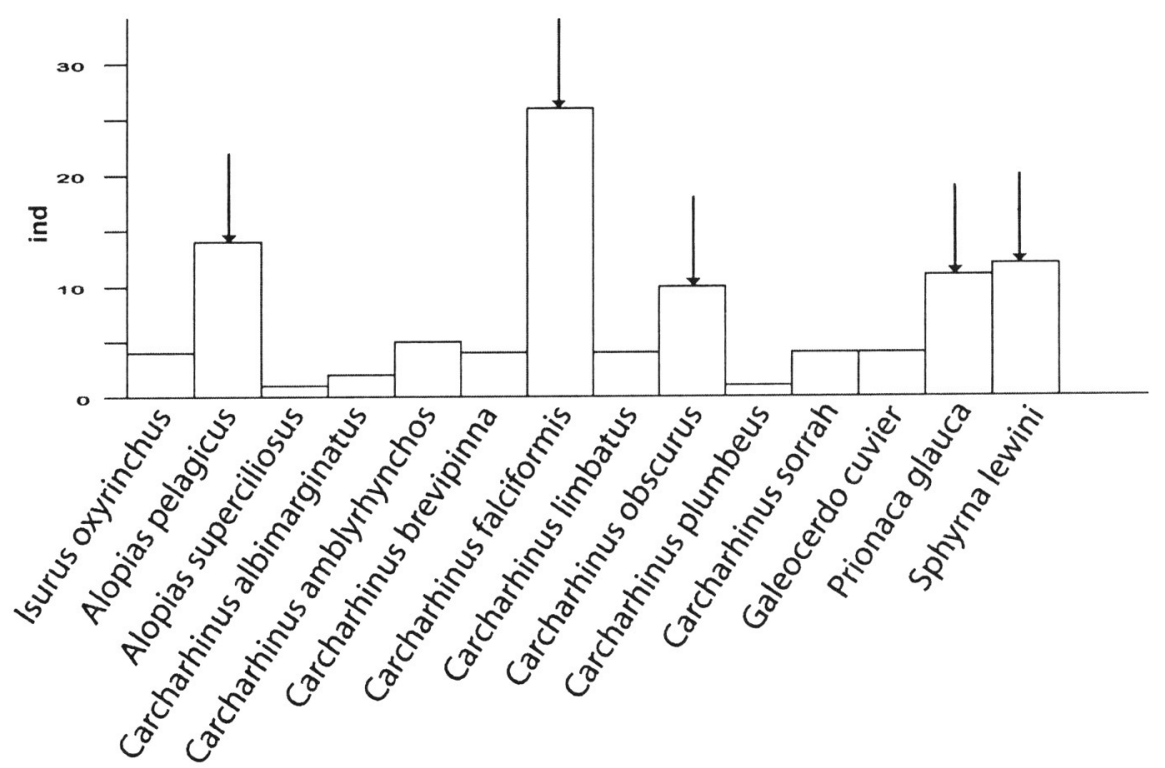

Figure 2. The most abundant shark species in Indian Ocean.

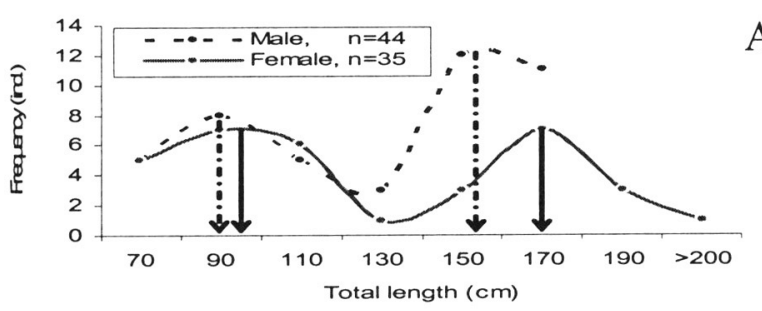

A
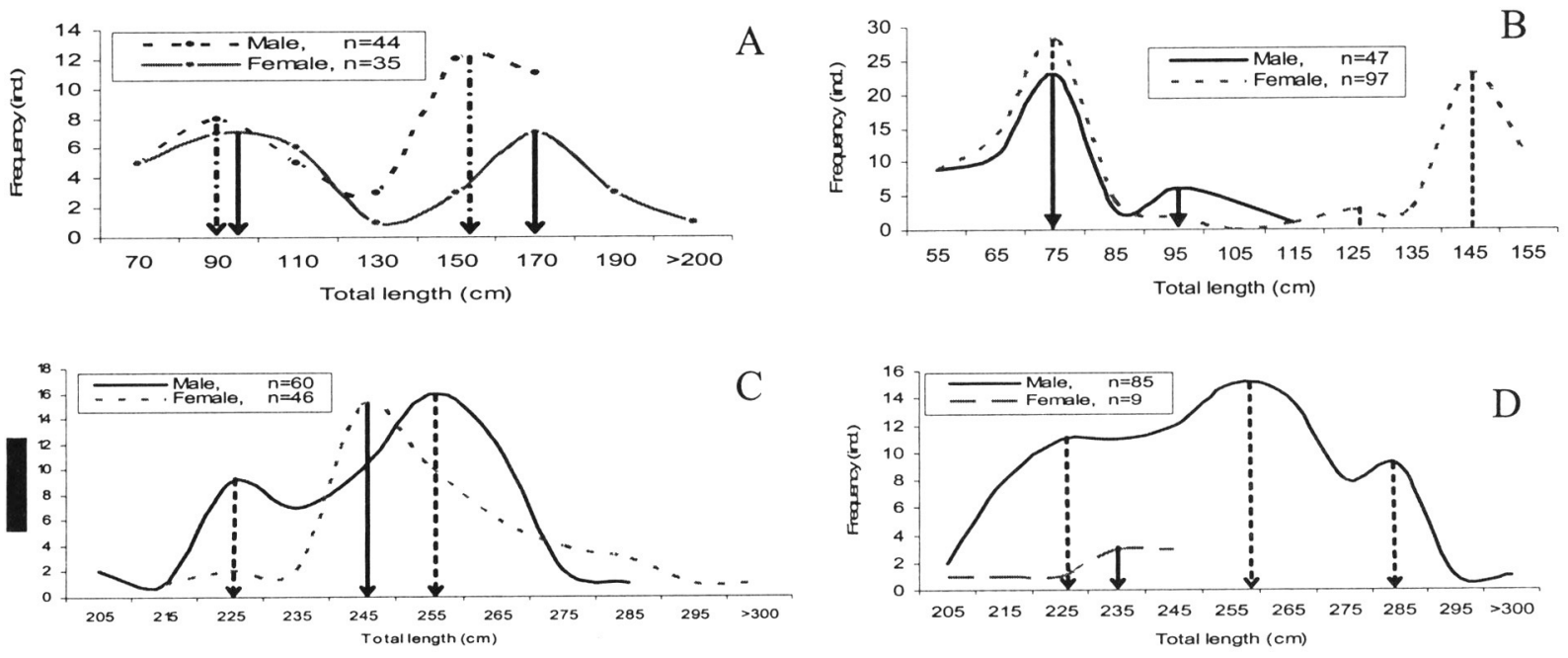

Figure 3. Length frequency distributions of (A) C. amblyrhynchos, (B) C. sorrah, (C) C. obscurus, and (D) $P$. glauca.

\section{Length frequencies}

Figure 3 showed that females of $C$. ambyrhynchos was abundant at size classes of $95 \mathrm{~cm}$ and $170 \mathrm{~cm}$, while males suggested to have high abundant at size classes of $90 \mathrm{~cm}$ and 150 $\mathrm{cm}$. Females $C$. sorrah had at least three abundant size classes with the peaks of length at $75 \mathrm{~cm}, 125$ $\mathrm{cm}$, and $145 \mathrm{~cm}$. The males of this shark species had at least two abundant size classes with the peaks at $75 \mathrm{~cm}$ and $95 \mathrm{~cm}$. Both females and males of $C$. obscurus had two abundant size classes with the peaks of length at $225 \mathrm{~cm}, 255 \mathrm{~cm}$ for males, while females were at $225 \mathrm{~cm}$ and $245 \mathrm{~cm}$, respectively. Meanwhile, Males of $P$. glauca were abundant at least at three size classes, with the peaks of length at $225 \mathrm{~cm}, 260 \mathrm{~cm}$, and $285 \mathrm{~cm}$.

The size composition according to their maturity stages were separated into three group of maturity level. Percentages of mature, immature and postmature sizes of four carcharhinid species from our observation are listed in Table 2.

\section{DISCUSSION}

According to Compagno (1997), fish markets could be the best places to collect shark sample 
Table 2. Percentage contribution of maturity stages (mature, immature and postmature) of four carcharhinid sharks from the Indian Ocean during the study.

\begin{tabular}{|l|c|c|c|c|}
\hline \multirow{2}{*}{ Species } & \multicolumn{4}{c|}{ Percentage } \\
\cline { 2 - 5 } & Mature & Immature & Postmature & Sex \\
\hline C. amblyrhinchos & 2.3 & 51.4 & 40 & Female \\
& 34.1 & 40.9 & 25 & Male \\
\hline C. sorrah & 1.03 & 58.8 & 40.2 & Female \\
& 10.6 & 89.4 & - & Male \\
\hline P. glauca & 22.2 & 11.1 & 66.7 & Female \\
& 22.4 & 2.4 & 75.3 & Male \\
\hline C. obscurus & 54.3 & 43.5 & 2.2 & Female \\
& 5 & 95 & - & Male \\
\hline
\end{tabular}

from the coastal areas as well as from the ocean. Moreover, the data also could be used to assess their abundance. However, the biodiversity study of sharks taken from fish markets was significantly different than those which came from a direct sampling study in certain water (Pers. obs.). Regarding from all landing sites, sharks were caught by various fishing gears, such as bottom long-lines, surface long-lines, gillnets, trammel nets, bottom trawls, and drop lines, both as target fisheries and also as by catch. In general, fisheries that catch sharks as by catch were usually operated using bottom trawls, trammel nets, gillnets, long-lines, and drop lines. While the target shark fisheries usually used gillnets, trammel nets, longlines, and harpoon as their fishing gears. Those fishing gears which utilized as target fisheries were particularly carried out in Tanjung Luar.

During our observation, we found as follows: At Cilacap, the most common shark species were Alopias pelagicus (Alopiidae) and Carcharhinus faciformis (Carcharhinidae). They were caught by surface gillnets and tuna long-lines. Whiles sharks that were caught by bottom long-lines were Centrophorus niaukang, Squalus sp. (Squalidae) and Hydrolagus sp. (Chimaeridae).

At Palabuhanratu, the most common shark species caught by surface long-lines were Carcharhinus falciformis and Prionace glauca (Carcharhinidae). While the common sharks caught by bottom long-lines was only Centrophorus niaukang (Centrophoridae). At Kedonganan, sharks were caught by using bottom gillnets and drop lines. The fishing-ground was about $5-10$ miles with the depth of about $50-$ $100 \mathrm{~m}$. The fishing trips are usually only $1-2$ days per trip. The common shark species from this landing site were Squalus sp. (Squalidae),
Carcharhinus brevipinna (Carcharhinidae), and Sphyrna lewini (Sphyrnidae). At Tanjung Luar, the catches were dominated by Carcharhinus amblyrhynchos, C. falciformis, C. sorrah, Galeocerdo cuvier, Triaenodon obesus (Carcharhinidae), and Sphyrna lewini (Sphyrnidae).

The fishing gears used at Tanjung Luar were bottom long-lines and surface long-lines. The fishing grounds were located at surrounding of southern Sabu Island, southern Nusa Tenggara Timur, eastern Sumba Island, western Flores Island, eastern Ende Island, and surrounding of Cempi Island with the depth of about $150 \mathrm{~m}$ using surface long-lines. The surface longlines have the length of about $12000-13000 \mathrm{~m}$, and the hook number of about 400-600 (no. 1); When using the bottom long lines, the fishers moved to the deeper fishing grounds such as at surrounding of Lombok, Sumbawa and Sumba Islands with the depth of about $100-200 \mathrm{~m}$. The bottom longlines were set at length of about $1.000-2.000 \mathrm{~m}$ with the hook number of about 100 (no. 1).

According to White et al., (2006) that the females of $C$. amblyrhynchos were mature at 125 $-135 \mathrm{~cm}$, and the mature males at $130-149 \mathrm{~cm}$. Females $C$. sorrah reach their maturity at $110-$ $118 \mathrm{~cm}$, and males at $103-115 \mathrm{~cm}$. While $C$. obscurus were mature at $257-300 \mathrm{~cm}$ for the females and at $280-300 \mathrm{~cm}$ for the males. Both sexes of $P$. glauca were mature at $210-220 \mathrm{~cm}$. Therefore, the four shark species above were caught at all maturity levels, some of them were caught at mature sizes and the rest at small and medium of immature sizes.

Figure 3 also shows that the females of $C$. sorrah were caught in equal number between the young and mature sizes. In coastal waters of 
Cleveland, the north-east Australia, most of $C$. sorrah were caught in various sizes from the young sizes to the mature sizes, which were between 54 $\mathrm{cm}$ and more than $86 \mathrm{~cm}$ (Colin and Milward, 1993). In this study, we found that the size composition of $C$. sorrah from the Indian Ocean was larger than those of the previous investigation. In general, most of $C$. amblyrhinchos and C.obscurus were caught in the maturing stages, C. sorrah was in immature and maturing stages while most of $P$. glauca were caught in the mature stages. However, more accurate information of their mature sizes is still needed. There was not significant differentiation yet in the length frequency of female $P$. glauca between the lowest and highest class, because limited samples were collected. Whereas for males, the smallest length were found on the size between $200-210 \mathrm{~cm}$ and the most common large sizes were found at the size of about $250-260 \mathrm{~cm}$ (Fig. 3d). The study result on the highest length frequency of males for the same species was similar in sizes to the result from Northeast Brazil. However, the size at the first gonad maturity in the both males and females of $P$. glauca that were found there was at the $225 \mathrm{~cm}$ and $228 \mathrm{~cm}$ (Lessa et al., 2003). In the Northeast Atlantic, the female $P$. glauca were caught from $64-228 \mathrm{~cm}$ with the peak length frequency distribution at $155 \mathrm{~cm}$ TL. While the male sizes distributed from $95-219 \mathrm{~cm}$ with the peak at 146 $\mathrm{cm}$ (Handerson et al., 2001). According to Hanan et al., (1993) the size of the mature males of $P$. glauca were about $153-183 \mathrm{~cm}$ in standard length, and when we observed the development of claspers, the gonad maturity of males was at the size of about $183 \mathrm{~cm}$ in standard length or $218 \mathrm{~cm}$ in total length.

\section{CONCLUSION}

In 2001-2006 we recorded about 86 species of them belonging to 16 families indicating high diversity of sharks from the Indian Ocean. The dominant families were Carcharhinidae and Squalidae, and the most common species of sharks was Carcharhinus falciformis. Shark fishery in Tanjung Luar was apparently as a target fish, whereas in the other sites were as by catch. The sizes of sharks of the Carcharhinidae were varied from small until medium sizes and some of them were in mature stages, particularly for P. glauca.
Acknowledgements. We thank to Dr. Stephen Blaber as a project leader from Commonwealth Scientific and Industrial Research Organization (CSIRO) Australia and ACIAR project team who helped collecting the data, especially to Dr. William White (Murdoch University Australia / CSIRO Hobart) and Ms. Jenny Giles.

\section{REFERENCES}

Anonymous. 2003. Shark fining. Unrecorded wastage on a global scale. Wild Aid. San Francisco. 11p.

Blaber, S.J.M. 2006. Artisanal shark and ray fisheries in Eastern Indonesia: their socioeconomic and fisheries characteristics and relationship with Australian resources. ACIAR PROJECT FIS/2003/ 037 supplementary stock assessment meeting, CSIRO Cleveland, Australia, 4 September, 2006. $57 \mathrm{p}$.

Carpenter, K.E., and V.H. Niem (eds). 1998. FAO Identification guide fishing purposes. The living marine resources of the Western Central Pacific. Vol. 2. Cephalopods, crustaceans, holothurians and sharks. FAO, Rome. p.687-1396.

Colin, A.S and N.E. Milward. 1993. Utilization of a tropical bay as a nursery area by sharks of the families Carcharhinidae and Sphyrnidae. Environmental Biological of Fishes. Kluvier Academic Publishers. Netherlands 37: 337-345.

Compagno, L.J.V. 1984. FAO species catalogue. Vol. 4. Sharks of the world. An annotated and illustrated catalogue of sharks species known to date. Part 1. Hexanchiformes to Lamniformes. FAO Fish. Synop. (125) vol. 4, pt 1:249p.

Compagno, L.J.V. 1997. Review of the Biodiversity of Sharks and Chimaeras in the South China Sea and Adjacent Areas. In: Elasmobranches Biodiversity, Conservation and Management. Proceedings of the International Seminar and Workshop, Sabah, Malaysia, July 1997. Occasional paper of the IUCN Species Survival Commissions no.25. p. 52-62.

Compagno L.J.V. 1998. Sharks. In: KE Carpenter, VH Niem (eds) FAO Species Identification Guide for Fishery Purposes. The living marine resources of the Western Central Pacific. Volume 2. Cephalopods, crustaceans, holuthurians and sharks. FAO, Rome. p.1193-1366.

Compagno L.J.V. 1999. Batoid Fishes. In: KE Carpenter, VH Niem (eds) FAO Species Identification Guide for Fishery Purposes. The living marine resources of the Western Central Pacific. Volume 3. Batoid fishes, chimaeras and bony fishes part 1 (Elopidae to Linophyrnidae). FAO, Rome. p.1397-1530. 
Dharmadi and Fahmi. 2003. Fisheries characteristics of artisanal sharks and rays in Indonesia waters. Paper in International Seminar on Marine and Fisheries. Agency for Marine and Fisheries Research, Ministry of Marine Affairs and Fishery: 122-129.

Demski, L.S. and J.P.Wourms. 1993. The Reproduction and Development of Sharks, Skates, Rays and Ratfishes Introduction, History, Overview, and Future Prospects. P: in the Reproduction and Development of Sharks, Skates, Rays and Ratfishes, by J.P. Wourms and L.S. Demski. Kluwer Academic Publishers. London. 299p.

Directorate General of Capture Fisheries, 2006. Capture fisheries statistics of Indonesia. DGCF-MMF, no.1, vol. 5, Jakarta. 130p.

FAO. 2000. Fisheries management. Conservation and Management of Sharks. Rome. 37p.

Gloerfelt-Tarp, T. and P.J. Kailola. 1984. Trawled Fishes of Southern Indonesia and Northwestern Australia. ADAB-DFG-GTZ, Singapore, 406p.

Hanan, D.A., B.H. David, and L.C.Jr. Atilio. 1993. The Califormia Drift Gill Net Fishery for Sharks and Swordfish, 1981-82 through 1990-91. State of California the Resources Agency Department of Fish and Game. Fish Bulletin. 175p.

Henderson, A.C., K. Flannery and J. Dunne, 2001. Observations on the biology and ecology of the blue shark in the North-east Atlantic. The Fisheries Society of the British Isles. Journal of Fish Biology (2001) 58: 1347-1358.
Last, P.R., and J.D. Stevens., 1994. Sharks and Rays of Australia. Fisheries Research and Development Corporation. 513p.

Lessa, R., F.M. Santana, and F.H. Hazin. 2003. Age and growth $f$ the blue shark Prionace glauca (Linnaeus, 1758) off northeastern Brazil. ELSEVIER. Fisheries Research 66 (2004): 19-30.

Monintja, D.R. and R.P. Poernomo 2000. Proposed concept for catch policy on shark and tuna including southern blue fin tuna in Indonesia. Paper presented at "Indonesian-Australian workshop on shark and tuna", Denpasar, March 2000. p. 1-12.

Sparre, P. and Venema, S.C. 1992. Introduction to tropical fish stock assessment. Part I-Manual. FAO Fisheries Technical paper. 306/1. Rev.1. Danida FAO, Rome, Italy. 376p.

Widodo, J. 2000. The Indonesian shark fisheries present status and the need for research for stock assessment and management. Paper presented at "Indonesian-Australian workshop on shark and tuna", Denpasar, March 2000. p.1-15.

White, W. T., P. R. Last, J.D. Stevens, G.K.Yearsley, Fahmi, and Dharmadi.2006. Economically important sharks and rays of Indonesia. ACIAR monograph series; no. 124,Perth, WA. 329p.

Wourms, J.P and Leo, S.D, 1993. The reproduction and development of sharks, skates, rays and ratfishes:introduction, history, overview, and future prospects. Environment Biology of Fishes 38:7-21, 1993. 15p. 